\title{
Insulin-like Growth Factor-1 Stimulation of Lymphopoiesis
}

\author{
Ross Clark, * Josef Strasser, * Susan McCabe, Kimberly Robbins, and Paula Jardieu \\ Departments of *Endocrine Research and Immunology, Genentech, Inc., South San Francisco, California 94080
}

\begin{abstract}
We show that treatment of adult mice with recombinant human insulin-like growth factor 1 (rhIGF-1) induces striking modifications in lymphocyte number and function. 9-mo-old male mice received rhIGF-1 ( $4 \mathrm{mg} / \mathrm{kg}$ per d) or its excipient by subcutaneous infusion from osmotic minipumps for 7 or $14 \mathrm{~d}$. Mice were weighed daily and bled at sacrifice; the spleen and thymus were harvested and single cell suspensions were made for analysis of cell phenotype and cell number. The responses of splenocytes to mitogens (concanavalin A, lipopolysaccharide, and pokeweed mitogen), alloantigens and dinitrophenyl ovalbumin were measured. After either 7 or $14 \mathrm{~d}$ of treatment, rhIGF-1 had an overall whole-body anabolic effect, resulting in increased body and organ weights with prominent increases in the weight of the spleen and thymus. Furthermore, the rhIGF-1 treated mice were normoglycemic but had reduced blood urea nitrogens, again reflecting the anabolic activity of rhIGF-1. The increased spleen and thymus weights were associated with a large increase in the number of lymphocytes in both organs. In addition to an increase in $\mathrm{T}$ cells, specifically $\mathrm{CD4}^{+} \mathrm{T}$ cells, a dramatic increase in splenic B cells was also observed. This increase was accompanied by an enhanced responsiveness to dinitrophenyl ovalbumin resulting in increased immunoglobulin production. However, despite the increases in cellularity, there was a decrease in the in vitro responses of spleen cells to mitogens after $7 \mathrm{~d}$ of rhIGF-1 treatment. In contrast, treatment with rhIGF-1 for $14 \mathrm{~d}$ increased both the cell number and mitogenic responses of splenocytes suggesting that some time is required for the cells populating the peripheral organs to gain mitogenic responsiveness. It is clear from these data that rhIGF-1, at doses that have whole-body anabolic activity, can expand cell number in lymphoid tissue in a normal adult mouse. These dual effects of rhIGF-1, of increasing lymphocyte number and activity, indicate that, in a normal adult animal, rhIGF1 can cause major changes in lymphoid tissues that are of potential benefit to the functioning of the immune system. ( $J$. Clin. Invest. 1993. 92:540-548.) Key words: B cells $\bullet \mathrm{CD}^{+} \mathrm{T}$ cells • immunoglobulin $\mathbf{G} \bullet$ lymphopoiesis • recombinant human insulin-like growth factor-1
\end{abstract}

Address reprint requests to Dr. Paula Jardieu, Department of Immunology, Genentech, Inc., 460 Pt. San Bruno Blvd. South San Francisco, CA $94080-4990$.

Received for publication 27 January 1993 and in revised form 26 March 1993.

J. Clin. Invest.

(c) The American Society for Clinical Investigation, Inc.

0021-9738/93/08/0540/09 \$2.00

Volume 92, August 1993, 540-548

\section{Introduction}

Insulin-like growth factor-1 (IGF-1), ${ }^{1}$ a 70 -amino acid peptide structurally related to insulin, is normally considered to be a metabolic hormone which mediates many of the anabolic effects of growth hormone (GH) (1). These anabolic activities of IGF-1 were initially quantitated in GH-deficient or hypophysectomized rats, and a common finding has been that recombinant human IGF-1 (rhIGF-1) increases spleen and thymus weight disproportionately to its effect on whole-body size (14). However, direct comparisons of the anabolic activities of GH and IGF-1 suggest that they have differential effects on organ growth. For example, GH has a large effect on epiphyseal cartilage growth while IGF-1 has a greater effect on splenic weight (3).

In addition to these established anabolic effects, there is a growing body of evidence that links growth hormone to the immune system (5-7). For example, mice with hereditary GH deficiency develop an impaired immune system associated with thymic atrophy, immunodeficiency, and tissue wasting which is believed to contribute to the shortened life expectancy of these mice (8). Conversely, administration of exogenous GH induces T-cell proliferation in the thymus $(9,10)$ and can alter the activity of all major immune cell types, including $\mathrm{T}$ cells, B cells, natural killer (NK) cells, and macrophages (11). It has been hypothesized that long-term, low-dose GH therapy increases immune function and life expectancy of aged BALB/c mice (12).

There are fewer reports on the direct effects of IGF-1 on immune parameters despite the possibility that the actions of GH on lymphocytes may be mediated by the local induction of IGF-1, which then acts through the type-1 IGF receptor (13). Indeed, recent data suggest that $B$ cells and activated $T$ cells possess receptors for IGF-1 $(14,15)$. Further, at nanomolar concentrations, IGF-1 has been shown in vitro to be a growthpromoting factor for lymphocytes and to be chemotactic for resting and activated $\mathrm{T}$ cells (16).

In addition to these effects on lymphocytes, IGF-1 has been reported to enhance the maturation of morphologically recognizable granulocytic and erythroid progenitors in suspension cultures of marrow cells (17). In vivo, infusions of rhIGF-1 increase thymus and spleen weight in hypophysectomized rats $(1,2)$ and dwarf rats $(3)$, and induce repopulation of the atrophied thymus in diabetic rats (4). In addition, there is a report in the rat that rhIGF-1 can enhance thymic recovery after cyclosporine treatment (18). These reports suggest that IGF-1 may have endocrine, paracrine, or autocrine effects on the immune system.

1. Abbreviations used in this paper: GH, growth hormone; PNA, peanut agglutinin; PWM, pokeweed mitogen; rhIGF-1, recombinant human insulin-like growth factor-1; SI, stimulation index; TdR, thymidine. 
The effects on lymphoid tissue after in vivo administration of rhIGF-1 have been described only in gross anatomical terms as an increased weight of spleen or thymus (1-4), whereas the studies in vitro have focused primarily on the effects on $T$ cells. There are few data describing the effects of in vivo administration of rhIGF-1 on the number, phenotype, or responsiveness of lymphocytes. We now show that short-term administration of rhIGF-1 to normal adult retired breeder mice has profound effects on lymphoid tissues owing to increases predominately in $\mathrm{CD}^{+} \mathrm{T}$ cells and, quite unexpectedly, B cell populations resulting in enhanced immunoglobulin synthesis. Interestingly, there is an associated but delayed increase in T and B cell responsiveness to mitogens after rhIGF-1 administration.

\section{Methods}

Animals. Male retired breeder BALB/c mice 9 mo old, weighing 25-35 g (obtained from Harlan Sprague Dawley, San Diego, CA), were housed in single cages in a light- and temperature-controlled room. Food (Rodent Chow 5010, Ralston Purina Co., St. Louis, MO) and water were given ad libitum, and the mice were identified with ear tags and acclimated for at least $1 \mathrm{wk}$ before treatment. The mice were then weighed and randomized into treatment groups to give groups of equal initial body weight.

Experimental design. Three independent studies, designated studies A, B, and C, were carried out to assess the effects of rhIGF-1 on immune parameters. In each study rhIGF-1 was given by subcutaneous (sc) infusion for either 7 (studies A and B) or $14 \mathrm{~d}$ (study C). In study $A$, three doses of rhIGF-1 were used to establish an effective anabolic dose of rhIGF-1 in normal mice. In study A, rhIGF-1 was given for $7 \mathrm{~d}$ to four groups of mice (six mice per group). The mice were implanted with pumps delivering $(a)$ excipient, $(b)$ rhIGF-1 at $7.5 \mu \mathrm{g} / \mathrm{d}(0.25$ $\mathrm{mg} / \mathrm{kg}),(c)$ rhIGF-1 at $30 \mu \mathrm{g} / \mathrm{d}(1 \mathrm{mg} / \mathrm{kg})$, or $(d)$ rhIGF-1 at 120 $\mu \mathrm{g} / \mathrm{d}(4 \mathrm{mg} / \mathrm{kg})$. In study B the highest dose of rhIGF-1 $(4.6 \mathrm{mg} / \mathrm{kg}$ per d) or excipient was administered for $7 \mathrm{~d}$ to the mice (five mice per group). In study C, a high dose of rhIGF-1 of $(4.6 \mathrm{mg} / \mathrm{kg}$ per d) or excipient were given for $14 \mathrm{~d}$ to the mice (six mice per group).

rhIGF-1 delivery. The rhIGF-1 $(5 \mathrm{mg} / \mathrm{ml})$ was given by continuous subcutaneous (s.c.) infusion from implanted osmotic minipumps (Alza Corp., Palo Alto, CA). For 7-d studies one pump (Alzet model 2001, pump rate $1 \mu \mathrm{l} / \mathrm{h}$ ) was implanted; for 14-d studies two pumps (Alzet model 2002, pump rate $0.5 \mu \mathrm{l} / \mathrm{h}$ ) were used. The pumps were filled, using sterile techniques, with rhIGF-1 or the excipient buffer, then preincubated overnight in saline to reduce the likelihood of an initial burst of rhIGF-1 release from the pump. The animals were anesthetized with an intraperitoneal (i.p.) injection of $0.4 \mathrm{ml}$ of avertin (6 $\mu \mathrm{g}$ of 2,2,2-tribromethanol in PBS). An incision was made in the dorsal scapular region and either one or two minipumps inserted caudally into the sc pocket and the incision closed with metal wound clips. An injection of penicillin $(7,500 \mathrm{U}$, s.c.) was then given and the animals were replaced in their individual cages. The mice were weighed and inspected daily.

Cell preparation. 7 or $14 \mathrm{~d}$ after the pumps were implanted, mice were bled by orbital puncture and killed by cervical dislocation, and the heart, liver, and kidneys were removed and weighed. The spleen and the thymus were removed, weighed, and placed in tissue culture medium on ice. The spleen and thymus were then individually dispersed between sintered glass slides to form single-cell suspensions. For use in the in vitro assays the cells were washed in Eagle's MEM (Gibco, Grand Island, NY), containing $10 \%$ FBS (Gibco), penicillin (100 U/ml), $100 \mu \mathrm{g} / \mathrm{ml}$ streptomycin (Gibco), and $200 \mathrm{mM}$ glutamine), and resuspended at $5 \times 10^{6}$ viable cells $/ \mathrm{ml}$. Cell viability was determined by trypan blue dye exclusion. Complete blood counts were obtained on peripheral blood samples.
Immunizations. Mice were primed by an i.p. injection of $1.0 \mu \mathrm{g}$ of dinitrophenyl ovalbumin ( $\left.\mathrm{DNP}_{2} \mathrm{OA}\right)$ absorbed to $1 \mathrm{mg}$ of aluminum hydroxide gel (alum). $21 \mathrm{~d}$ postimmunization, mice were given a booster injection of $1.0 \mu \mathrm{g} \mathrm{DNP}{ }_{2} \mathrm{OA}$ in alum and implanted with the minipumps releasing rhIGF-1 ( $4 \mathrm{mg} / \mathrm{kg}$ per $\mathrm{d}$ for $14 \mathrm{~d})$ or rhIGF-1 excipient.

In vitro immunoglobulin synthesis. 2 wk after pump implantation, spleens were removed, single-cell suspensions were made, and splenocytes were stimulated for IgG synthesis. Splenocytes $\left(2 \times 10^{5}\right.$ cells $\left./ \mathrm{ml}\right)$ were incubated in $200 \mu \mathrm{l}$ of MEM. DNP ${ }_{2} \mathrm{OA}(10 \mu \mathrm{g} / \mathrm{ml})$ was added at the initiation of culture. Cultures were incubated in $5 \% \mathrm{CO}_{2}$ at $37^{\circ} \mathrm{C}$ for $96 \mathrm{~h}$. Supernantants were harvested and the total IgG antibody concentration was measured using the ELISA format described.

Measurement of IgG antibodies: total IgG. IgG antibodies in the culture supernatants were measured by an ELISA using 96-well plates and murine IgG as a reference standard. Each well was coated with 0.1 ml of 1:200 goat anti-murine IgG-Fc specific antibody (Cappel Laboratories, Westchester, PA) for $24 \mathrm{~h}$ at $4^{\circ} \mathrm{C}$. After blocking with $0.1 \% \mathrm{BSA}$, $0.1 \mathrm{ml}$ of culture supernatant was added in triplicate to the coated plates. After a 2-h incubation at room temperature, the plates were washed three times with PBS $/ 0.02 \%$ Tween 20 , and $0.1 \mathrm{ml}$ of a 1:5,000 dilution of horseradish peroxidase conjugated-Fab specific goat antimouse IgG (Boehringer Mannheim Biochemicals, Indianapolis, IN) was added. The plates were incubated for an additional $2 \mathrm{~h}$ and washed, and $0.1 \mathrm{ml}$ of $0.2 \mathrm{mg} / \mathrm{ml} o$-phenylenediamine, $0.01 \% \mathrm{H}_{2} \mathrm{O}_{2}$ in PBS was added to each well, the reaction was stopped with $2 \mathrm{M} \mathrm{H}_{2} \mathrm{SO}_{4}$ after 30 min, and the OD was read at $490 \mathrm{~nm}$ on a plate reader (Molecular Devices Corp., Menlo Park, CA).

Mitogen stimulation. For the mitogen assays LPS (Escherichia coli 0111:B4) was obtained from Sigma Chemical Co. (St. Louis, MO), pokeweed mitogen ( PWM) and concanavalin A (Con A) from Calbiochem Corp. (San Diego, CA). The response to each mitogen was assayed in triplicate at three concentrations: LPS $(100,10,1 \mu \mathrm{g} / \mathrm{ml})$, PWM $(10,5,2.5 \mu \mathrm{g} / \mathrm{ml})$, and Con A $(10,5,2.5 \mu \mathrm{g} / \mathrm{ml})$. The cells ( 1 $\times 10^{5}$ cells in $200 \mu \mathrm{l}$ ) were cultured in these dilutions of mitogen in flat-bottom microtiter plates (Falcon Plastics, Oxnard, CA) in complete MEM containing 10\% FBS and supplements. Cultures were incubated at $37^{\circ} \mathrm{C}$ in $10 \% \mathrm{CO}_{2}$ for $72 \mathrm{~h}$, then pulsed with $1 \mu \mathrm{Ci} /$ well of [ $m e t h y l-{ }^{3} \mathrm{H}$ ] thymidine $(67 \mathrm{Ci} / \mathrm{mmol} \mathrm{New} \mathrm{England} \mathrm{Nuclear,} \mathrm{Boston,}$ $\mathrm{MA}$ ) and harvested $6 \mathrm{~h}$ later onto glass fiber filters using a multiple sample harvester. Discs were dried and placed in $3 \mathrm{ml}$ of scintillation fluid, $\left[{ }^{3} \mathrm{H}\right]$ thymidine incorporation into DNA was measured using a scintillation counter (LS1701, Beckman Instruments, Inc., Palo Alto, $\mathrm{CA}$ ), and triplicate determinations were averaged. Mitogen responses are expressed as the stimulation index (SI), which is the ratio of the radioactivity (cpm) at the maximally stimulated concentration divided by the cpm in control nonmitogen-stimulated cultures.

Mixed lymphocyte reactions. One-way murine mixed lymphocyte cultures were established in 96-well flat-bottomed microtiter plates according to the method of Ranges et al. (19). Briefly, $1.5 \times 10^{5}$ responder splenocytes from either excipient or rhIGF-1-treated mice were cocultured with an equal number of allogeneic irradiated $(2,500 \mathrm{rad})$ stimulator splenocytes in $200 \mu \mathrm{l}$ of complete medium. Cultures were incubated at $37^{\circ} \mathrm{C}$ in $5 \% \mathrm{CO}_{2}$ for $5 \mathrm{~d}$, then pulsed with $\mathrm{I}$ $\mu \mathrm{Ci} /$ well of $\left[{ }^{3} \mathrm{H}\right]$ thymidine $(\mathrm{TdR})$ for $16 \mathrm{~h} .\left[{ }^{3} \mathrm{H}\right] \mathrm{TdR}$ incorporation was measured with the Beckman scintillation counter and triplicate determinations were averaged. Data are expressed as net $\mathrm{cpm}$. The mean $\left[{ }^{3} \mathrm{H}\right] \mathrm{TdR}$ incorporated by control cultures was $<1,000 \mathrm{cpm}$.

Phenotypic analysis of lymphoid populations. Lymphocyte cell suspensions, prepared as described above, were adjusted to $1 \times 10^{6}$ cells/ $\mathrm{ml}$ in PBS containing $0.1 \% \mathrm{BSA}$ and $10 \mathrm{mM}$ sodium azide. To stain the $T$ cell populations, the cell suspensions $(200 \mu \mathrm{l})$ were incubated for 30 min at $4^{\circ} \mathrm{C}$ with $5 \mu \mathrm{l}$ of the appropriate dilution of FITC-conjugated rat anti-mouse Thy-1, L3T4, Lyt-2, (Caltag, S. San Francisco, CA) or FITC-conjugated peanut agglutinin (PNA) (Sigma Chemical Co.). The B cells were stained using FITC-conjugated $\mathrm{F}\left(\mathrm{ab}^{\prime}\right)_{2}$ polyclonal goat anti-mouse Ig (IgM, IgG, IgA specific) (Cappell-Organon Tek- 
Table I. Anabolic Effects of rhIGF-1 in Normal Mice

\begin{tabular}{lcccc}
\hline Group (dose, $m g / k g$ ) & Wt gain & Liver wt & Heart wt & Kidney wt \\
\hline & $g$ & $g$ & $m g$ & $m g$ \\
Study A & & & & \\
$\quad$ Excipient & $0.7 \pm 0.7$ & $1.8 \pm 0.2$ & $190 \pm 29$ & $574 \pm 80$ \\
rhIGF-1 (0.25) & $0.9 \pm 0.6$ & $1.9 \pm 0.2$ & $180 \pm 21$ & $589 \pm 39$ \\
rhIGF-1 (1.0) & $1.3 \pm 1.0$ & $2.0 \pm 0.3$ & $200 \pm 17$ & $626 \pm 64$ \\
$\quad$ rhIGF-1 (4.0) & $3.4 \pm 1.2^{\ddagger}$ & $1.8 \pm 0.2$ & $191 \pm 16$ & $665 \pm 64^{*}$ \\
Study B & & & & \\
$\quad \begin{array}{l}\text { Excipient } \\
\text { rhIGF-1 (4.0) }\end{array}$ & $1.3 \pm 0.5$ & $1.9 \pm 0.1$ & $186 \pm 18$ & $549 \pm 29$ \\
Study C & & $1.7 \pm 0.1^{*}$ & $194 \pm 44$ & $658 \pm 21^{\S}$ \\
$\quad \begin{array}{l}\text { Excipient } \\
\text { rhIGF-1 (4.6) }\end{array}$ & $1.5 \pm 0.5$ & $1.7 \pm 0.1$ & $195 \pm 21$ & $556 \pm 59$ \\
& & $1.7 \pm 0.1$ & $199 \pm 25$ & $657 \pm 40^{*}$ \\
\hline
\end{tabular}

The body weight gain and the wet weights of the liver, heart, and kidney are shown for mice treated for $7 \mathrm{~d}$ (studies A and B) or $14 \mathrm{~d}$ (study C). The mice received minipumps delivering rhIGF-1 $(120 \mu \mathrm{g} /$ $\mathrm{d}$ per mouse) or excipient. Means and standard deviations are shown. Statistical significance is indicated as: ${ }^{*} P<0.05,{ }^{\ddagger} P<0.01,{ }^{\S} P$ $<0.001$ vs. excipient treated mice.

nika, West Chester, PA). After three washes with cold medium, cells were analyzed for degree of fluorescence intensity using a FACScan (Becton Dickinson \& Co., Sunnyvale, CA). Fluorescence parameters were collected using a log amplifier after gating on the combination of forward and perpendicular light scatter. Fluorescence data was expressed as percentage of fluorescent cells compared to a nonrelevant $\mathrm{mAb}$ of an identical isotype. Fluorescence was measured as mean intensity of the cells expressed as mean channel number plotted on a log scale.

Blood analyses. Blood glucose (coupled hexokinase procedure), cholesterol, globulin, total protein, blood urea nitrogen, and creatinine were measured in the sera using a Monarch 2000 Chemical Systems instrument (Allied Instrument Laboratories, Lexington, MA). Total serum IGF-1 was measured after acid-ethanol extraction by radioimmunoassay, using rhIGF-1 (M3-RD1, Genentech, Inc., S. San Francisco, CA) as the standard and rabbit anti-IGF-1 antiserum kindly supplied by Dr. P. Gluckman (University of Auckland, New Zealand). The acceptable range was $1.25-40 \mathrm{ng} / \mathrm{ml}$, while intra- and interassay variability were $5-9 \%$ and $6-15 \%$, respectively.

Statistical analysis. Statistically significant differences between treatment groups were established by analysis of variance, and for study A follow-up comparisons between individual groups were made using Duncan's Multiple Range Test. Differences were judged to be statistically significant if $P<0.05$. In the text and in the figures all data shown are means and standard deviations.

\section{Results}

Anabolic effects. Table I shows the body and organ weights after treatment with the various doses of rhIGF-1. Because the control mice were $>9 \mathrm{mo}$ of age, and therefore in growth stasis, only small weight gains were observed in the control mice during the treatment interval. However, it is clear that rhIGF-1 produced a dose related anabolic response. In all three of the studies, there was a highly consistent increase in body weight gain in the rhIGF-1-treated mice compared with excipienttreated controls. In study A there was a dose-related effect of rhIGF-1 on body weight gain over the $7 \mathrm{~d}$ ( excipient $0.75 \pm 0.75$ $\mathrm{g}$, low dose $0.86 \pm 0.63 \mathrm{~g}$, medium dose $1.31 \pm 1.03 \mathrm{~g}$, and high dose $3.42 \pm 1.24 \mathrm{~g}$ ). Only the highest dose of rhIGF-1 gave statistically significant anabolic effects $(P<0.001)$ and therefore this dose of rhIGF-1 (4 mg/kg per d) was chosen for further analysis.

Serum chemistries (Table II) reflected the modest but statistically significant metabolic effects of rhIGF-1. In all three studies there were significant declines in total serum protein, globulin, and cholesterol. Blood urea nitrogen levels fell in two of the studies (B and C). Significant reductions in glucose (study B) and creatinine (study C) occurred less frequently. Thus the effects on lymphoid tissues were observed at doses of rhIGF-1 that produced only modest metabolic effects. While serum IGF-1 concentrations were not measured in these studies, serum levels of the hormone were examined in subsequent studies. In those experiments, serum IGF-1 concentrations were doubled by $14 \mathrm{~d}$ of rhIGF-1 treatment. Mice receiving excipient pumps had serum IGF-1 concentrations that averaged $190 \pm 23 \mathrm{ng} / \mathrm{ml}(n=10)$ and in the mice receiving rhIGF$1(120 \mu \mathrm{g} / \mathrm{d}$ per mouse $)$ serum IGF-1 concentrations averaged $392 \pm 55 \mathrm{ng} / \mathrm{ml}(n=8)$.

The organ weights of excipient-treated mice were very consistent across the studies. There was no significant effect of rhIGF-1 on heart weight in any of the studies. In study B a small, but statistically significant, decrease in liver weight was observed in the IGF-1 treated mice compared to controls ( 1.7 vs. $1.9 \mathrm{~g})$. There was no effect on liver weight after rhIGF-1 treatment in the other two studies. The organs that did show

Table II. Effect of rhIGF-1 on Serum Chemistries of Normal Mice

\begin{tabular}{|c|c|c|c|c|c|c|}
\hline & \multicolumn{2}{|c|}{ Study A } & \multicolumn{2}{|c|}{ Study B } & \multicolumn{2}{|c|}{ Study C } \\
\hline & Excipient & rhIGF-1 & Excipient & rhIGF-1 & Excipient & rhIGF-1 \\
\hline Total protein $(g / d l)$ & $5.0 \pm 0.3$ & $4.5 \pm 0.2^{\ddagger}$ & $5.2 \pm 0.2$ & $4.8 \pm 0.2^{\ddagger}$ & $5.3 \pm 0.2$ & $4.8 \pm 0.2^{\ddagger}$ \\
\hline Globulin $(g / d l)$ & $2.2 \pm 0.1$ & $1.8 \pm 0.1^{\ddagger}$ & $2.5 \pm 0.1$ & $2.2 \pm 0.2$ & $2.4 \pm 0.3$ & $1.9 \pm 0.1^{\ddagger}$ \\
\hline Urea nitrogen $(\mathrm{mg} / \mathrm{dl})$ & $25.8 \pm 3.3$ & $24.2 \pm 2.4$ & $28.4 \pm 3.4$ & $23.0 \pm 2.8^{*}$ & $30.6 \pm 2.1$ & $25.0 \pm 3.7^{\ddagger}$ \\
\hline Creatinine $(m g / d l)$ & $0.4 \pm 0.05$ & $0.4 \pm 0.05$ & $0.4 \pm 0.07$ & $0.3 \pm 0.09$ & $0.58 \pm 0.08$ & $0.48 \pm 0.04^{*}$ \\
\hline Cholesterol $(m g / d l)$ & $119 \pm 9$ & $104 \pm 8^{\ddagger}$ & $124 \pm 6$ & $112 \pm 5^{\ddagger}$ & $128 \pm 10$ & $98 \pm 4^{8}$ \\
\hline Glucose $(m g / d l)$ & $166 \pm 14$ & $133 \pm 20$ & $137 \pm 15$ & $116 \pm 9^{*}$ & $148 \pm 14$ & $133 \pm 28$ \\
\hline
\end{tabular}

The serum chemistries in terminal bleeds taken from mice treated for $7 \mathrm{~d}$ (studies A and B) or for $14 \mathrm{~d}$ (study C) with either rhIGF-1 or excipient. Statistically significant effects are indicated as: ${ }^{*} P<0.05,{ }^{\ddagger} P<0.01$, and ${ }^{\circledR} P<0.001$. Means and standard deviations are shown. 
the expected increases in weight were the kidney, spleen, and the thymus. The effects of rhIGF-1 on kidney weights were modest, representing $10-15 \%$ increases over control values. In contrast, after high-dose rhIGF-1, the spleen weight was greatly increased, nearly doubling compared to controls after $7 \mathrm{~d}$ (Fig. $1, t o p)$. No further increase in size occurred after the 14-d treatment. The thymus also showed a large and statistically significant increase in size by day 7 (Fig. 1 b), which was maintained by $14 \mathrm{~d}$ of treatment.

Effect of 7-d rhIGF-1 treatment on lymphocyte subsets. The increased spleen weight after $7 \mathrm{~d}$ of $4 \mathrm{mg} / \mathrm{kg}$ rhIGF-1 was due in large part to an increase in lymphocyte number. Viable lymphocytes, as determined by trypan blue exclusion, increased from $20 \times 10^{6}$ cells/spleen for excipient to $50 \times 10^{6}$ cells / spleen in the rhIGF-1-treated mice (Fig. $2 a$ ). When B and T cell populations were then quantitated by FACS analyses of sIg-positive and Thy 1-positive cells, respectively the ratio of $B$
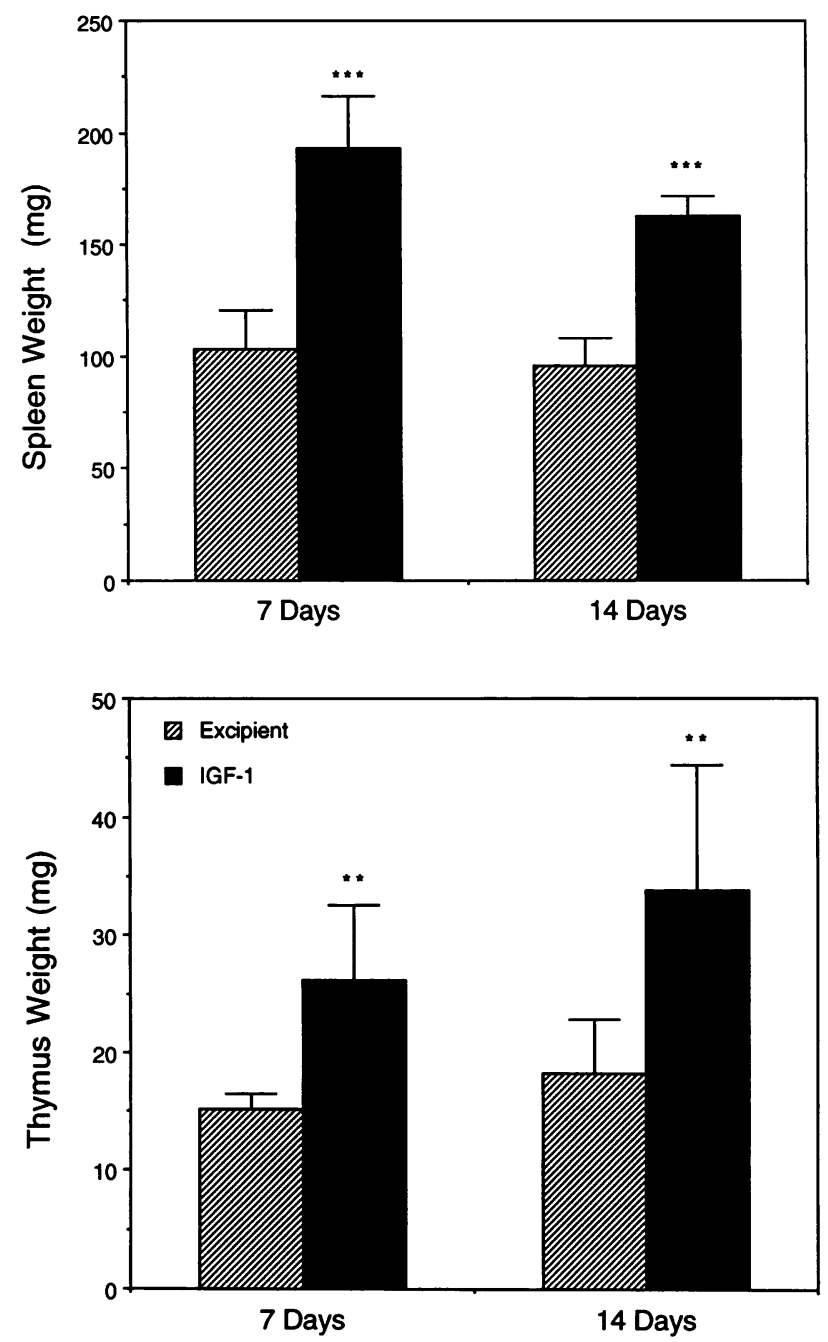

Figure 1. The weights of spleen (top panel) and thymus (bottom panel) in adult mice treated with rhIGF-1 (solid bars) or excipient (hatched bars). The length of treatment was either $7 \mathrm{~d}$ (on the left, study B) or $14 \mathrm{~d}$ ( on the right, study C). Treatment with rhIGF-1 (4 $\mathrm{mg} / \mathrm{kg}$ per d) dramatically increased both spleen and thymus weight. Treated groups were compared with their respective excipient-treated controls $\left({ }^{* *} P<0.01,{ }^{* * *} P<0.001\right)$. Means and standard deviations are shown in all figures.
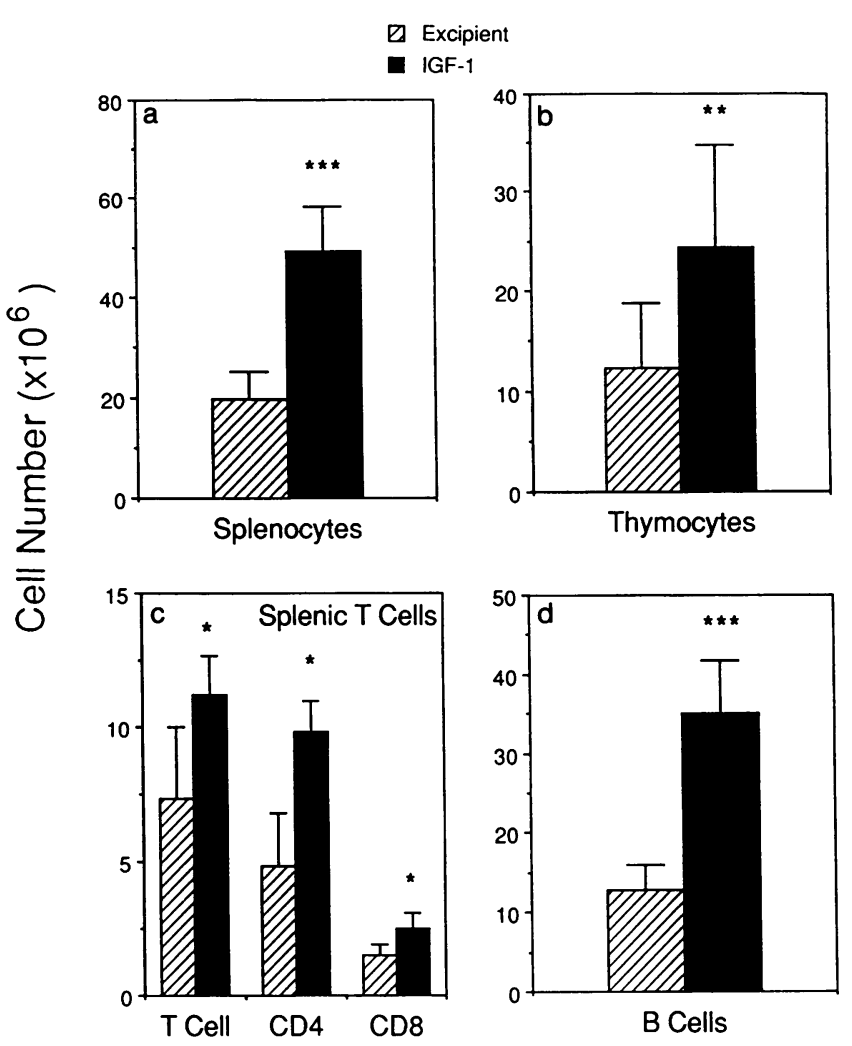

Figure 2. Total lymphocyte number in the thymus $(a)$ and spleen $(b)$ in mice treated with rhIGF-1 (solid bars) or excipient (hatched bars) for $7 \mathrm{~d}$. Treatment with rhIGF-1 $(4 \mathrm{mg} / \mathrm{kg}$ per d) increased thymic and splenic lymphocyte number $\left({ }^{*} P<0.05,{ }^{* * *} P<0.001\right)$. Treatment with rhIGF-1 also increased splenic $\mathrm{T}$ cell number $(c)$ and $B$ cell number $(d)$. Treated groups were compared with their respective excipient treated controls $\left({ }^{*} P<0.05,{ }^{* * *} P<0.001\right)$.

to $\mathrm{T}$ cells was changed from 1.9 to 3.0 reflecting a differential increase in the B cell fraction. However, the increase in cell number was due to an increase in both $B$ and $T$ cells. $B$ cell number in the spleen increased threefold (excipient $13 \times 10^{6}$ cells vs. rhIGF-1 $35 \times 10^{6}$ cells), whereas the $\mathrm{T}$ cell number increased to a lesser (excipient $7 \times 10^{6}$ cells vs. rhIGF-1 11 $\times 10^{6}$ cells) but was still statistically significant $(P<0.05)$ (Fig. 2, $c$ and $d$ ).

The increased thymic weight after rhIGF-1 treatment correlated with a significant increase in the number of Thy 1-positive thymocytes $\left(12 \times 10^{6}\right.$ for excipient treated vs. 24 $\times 10^{6}$ for rhIGF-1 treated) (Fig. $2 b$ ). There were no changes in the percentage or mean fluorescent intensity (MFI) in Thy-1, CD4, or CD8 expression on double-positive or single-positive thymocytes as a result of rhIGF-1 treatment. However, there was a consistent and statistically significant $(P<0.05)$ increase in PNA binding to thymocytes from rhIGF-1-treated mice compared to controls. The data from the 7-d experiment is shown in Fig. 3. Similar results were observed after $14 \mathrm{~d}$ of hormone treatment. In subsequent experiments, peripheral lymph nodes were examined and found to be significantly increased in weight and lymphocyte number (data not shown). Interestingly, the peripheral blood lymphocyte counts decreased from $60 / \mathrm{cm}^{3}$ in the controls to $50 / \mathrm{cm}^{3}$ in the treated mice. Monocyte and eosinophil counts were unchanged. The only statistically significant change in peripheral blood leuko- 


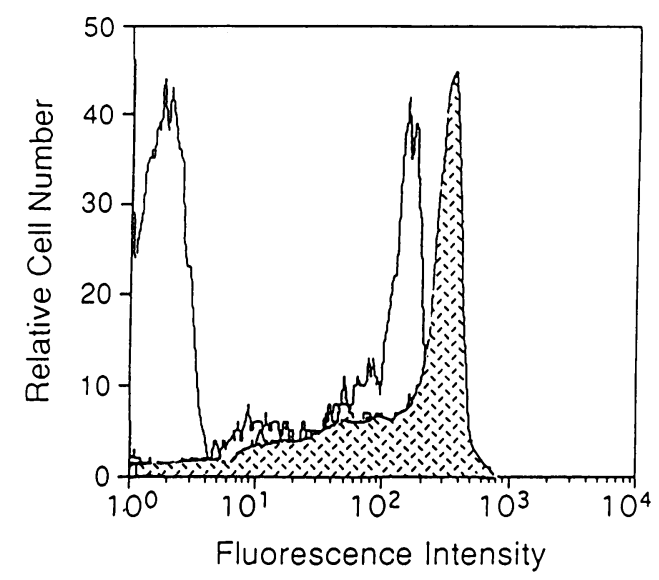

Figure 3. PNA binding as a marker of immature thymocytes was assessed. FACS profiles reveal a significant increase in FITC-PNA binding to thymocytes after high-dose rhIGF-1 treatment for $7 \mathrm{~d}$ (stippled) compared with thymocytes from excipient-treated mice (open) $(P<.05)$.

cytes $(P<0.01)$ was in the neutrophil count which increased from $33 \%$ to $48 \%$ after rhIGF-1 treatment.

When the subpopulations of $\mathrm{T}$ cells in the spleen were identified in these mice (Fig. $2 c$ ) it was found that $\mathrm{CD}^{+}$cells were doubled in number (excipient $4.8 \times 10^{6}$ cells vs. rhIGF-1 9.8 $\times 10^{6}$ cells). The number of $\mathrm{CD}^{+}$cells in the spleen was also significantly increased (from $1.5 \times 10^{6}$ to $2.5 \times 10^{6}$ ). However, the increase in $\mathrm{CD}^{+}$cells was smaller than the increase in the number of $\mathrm{CD}_{4}{ }^{+}$cells resulting in an increase in the helper/ suppressor ratio from 3.0 in control mice to 4.1 in the treated mice. However, this increase was not statistically significant.

In contrast to this dramatic increase in lymphocyte number, the mitogenic responses of splenic lymphocytes (see Fig. 5) from rhIGF-1-treated mice were decreased compared to controls. Both B (LPS) and T cell (Con A) responses were decreased, but only the decline in Con A responsiveness reached statistical significance. The decreased response to PWM, which reflects both $\mathrm{T}$ and $\mathrm{B}$ cell proliferation, was probably due to effects on the $\mathrm{T}$ cell compartment. The stimulation indices reported represent the peak of the proliferative response. The kinetics of the response and concentration of mitogens required for optimal stimulation were identical for both rhIGF1-treated and control mice.

Effect of 14-d rhIGF-1 on lymphocyte subsets. It was clear that $7 \mathrm{~d}$ of rhIGF-1 increased lymphocyte number but failed to increase lymphocyte function, as measured by mitogen stimulation. Therefore, a similar dose of $\mathrm{rhIGF}-1$ ( $4 \mathrm{mg} / \mathrm{kg}$ per $\mathrm{d})$ was given for a longer time ( $14 \mathrm{~d}$ ) to test the hypothesis that a longer exposure to rhIGF-1 might be necessary to stimulate lymphocyte function.

The effects of 14-d rhIGF-1 treatment on lymphoid size and cellularity completely paralleled the results observed with the 7-d treatment period. The weights of the thymus and spleen of the rhIGF-1 mice were significantly increased compared with controls and, as seen previously, the lymphocyte number in these organs nearly doubled compared with controls after 14 d of rhIGF-1 treatment (Fig. 4, $a$ and $b$ ). Substantial increases in splenic $B$ cell number and modest but significant increases in splenic $\mathrm{T}$ cell number were observed (Fig. 4, $c$ and $d$ ). The increase in $\mathrm{T}$ cell number once again was due to a large and

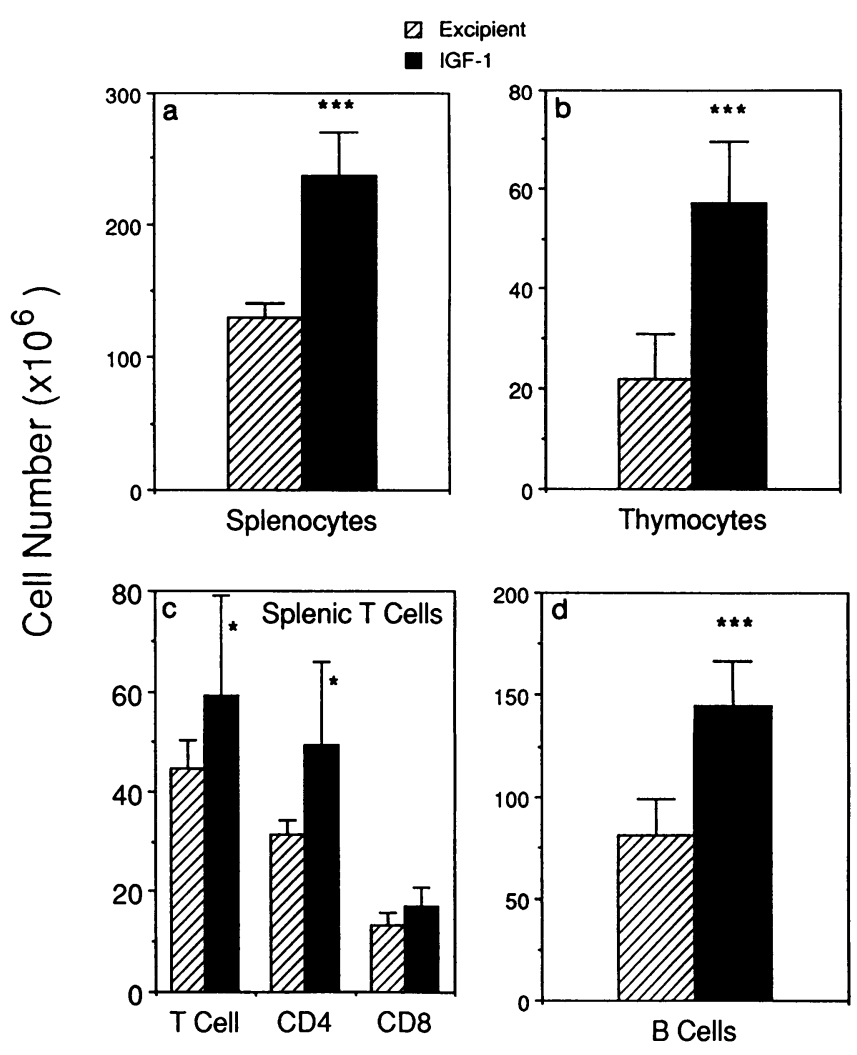

Figure 4. Total lymphocyte number in the thymus $(b)$ and spleen $(a)$ in mice treated with rhIGF-1 (solid bars) or excipient (hatched bars) for $14 \mathrm{~d}$. Treatment with rhIGF- $1(4 \mathrm{mg} / \mathrm{kg}$ per d) increased thymic and splenic lymphocyte number. $\left({ }^{*} P<0.05,{ }^{* * *} P<0.001\right)$, and increased splenic T cell number $(c)$ and B cell number $(d)$. The absolute effect on B cells was much greater than on $T$ cells. Treated groups were compared with their respective excipient-treated controls $\left({ }^{*} P<0.05,{ }^{* * *} P<0.001\right)$.

statistically significant increase in the $\mathrm{CD}^{+}$population (from $31 \times 10^{6}$ for excipient to $49 \times 10^{6}$ for rhIGF-1-treated) and a smaller increase in the number of $\mathrm{CD}^{+}$cells $\left(13.2 \times 10^{6}\right.$ for excipient vs. $17.1 \times 10^{6}$ for rhIGF-1-treated). Similar to the results seen at $7 \mathrm{~d}$, the helper/suppressor ratio for the rhIGF-1treated mice was somewhat elevated compared with controls ( 2.9 rhIGF-1; 2.4 excipient) but did not reach statistical significance.

In contrast to the decreased mitogenic response seen after 7 d of rhIGF-1, the mitogenic response of splenocytes from mice treated for $14 \mathrm{~d}$ with rhIGF-1 was significantly elevated compared to controls (Fig. 5). The SIs for Con A, PWM, and LPS were all increased greater than fourfold by treatment with rhIGF-1. Likewise, the mitogenic response of lymphocytes from the popliteal and mesenteric lymph nodes were also elevated as a result of hormone treatment. The Con A response of the lymph node cells increased twofold $(\mathrm{SI}=16.2 \pm 4$ excipient; $41.3 \pm 8$ rhIGF-1 $)$ as did the PHA response $(\mathrm{SI}=11.2 \pm 3$ excipient, $21.1 \pm 2$ rhIGF-1) compared to controls. These data support the notion that 7-d administration of rhIGF-1 results in significant increases in both $\mathrm{T}$ and $\mathrm{B}$ lymphocyte numbers, but additional time is required to see alterations in lymphocyte responsiveness.

There were differences in the initial numbers of $B$ and $T$ cells in the spleens of the control mice used in experiments B 

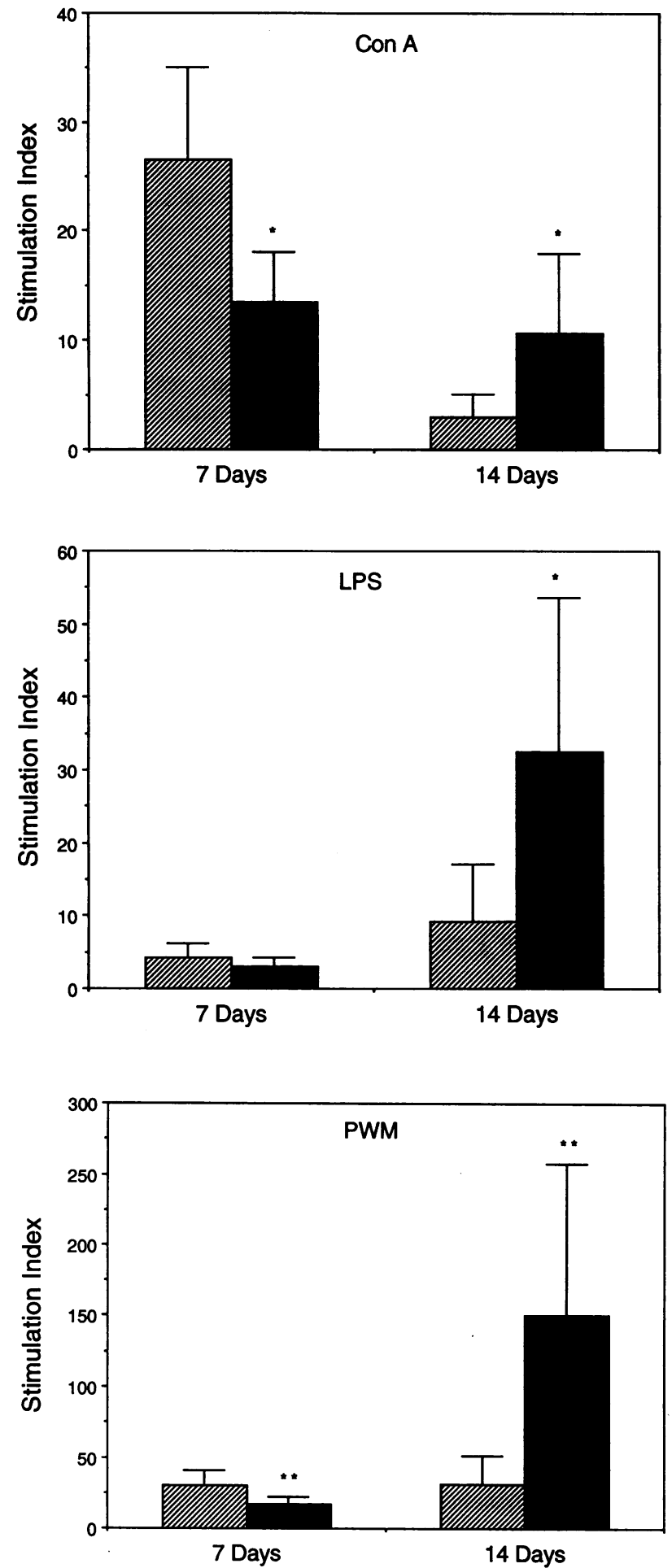

Figure 5. The stimulation indices are shown for the in vitro responses to mitogens of splenocytes harvested from treated animals. Con A ( upper panel) stimulates T cells, LPS (middle panel) stimulates B cells, and PWM (lower panel) stimulates T and B cells. The mice were treated with rhIGF-1 (solid bars) or excipient (hatched bars) for either 7 or $14 \mathrm{~d}$. After $7 \mathrm{~d}$ treatment with IGF-1, mitogen responses were reduced (baseline $\left[{ }^{3} \mathrm{H}\right] \mathrm{TdR}$ incorporation was $125 \pm 65$ excipient vs. $142 \pm 47$ rhIGF-1). After $14 \mathrm{~d}$ of treatment, increased mitogen responses were seen in the rhIGF-1-treated mice (baseline [ ${ }^{3} \mathrm{H}$ ] TdR incorporation was $290 \pm 30$ excipient vs. $268 \pm 23$ rhIGF-1). Treated groups were compared with their respective excipient-treated controls $\left({ }^{*} P<0.05\right)$.

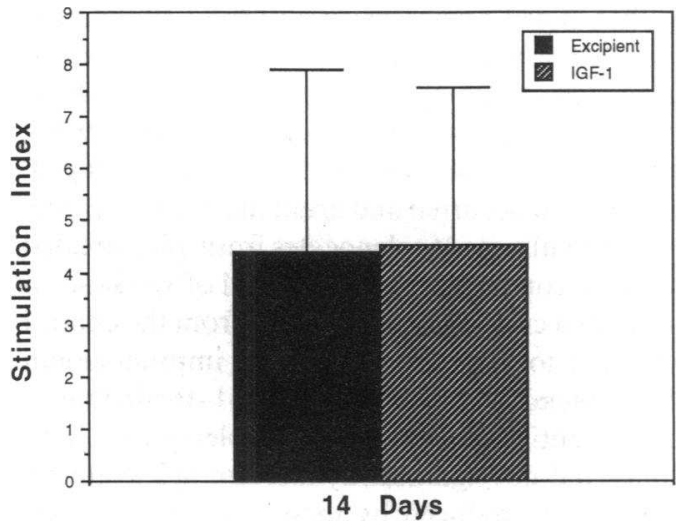

Figure 6. Effect of rhIGF-1 on the mixed lymphocyte reaction responder cells $\left(1.5 \times 10^{5}\right)$ from excipient or rhIGF-1-treated mice were cultured with $\left(1.5 \times 10^{5}\right)$ irratiated stimulator cells from an allogeneic donor for $5 \mathrm{~d}$ (baseline $\left[{ }^{3} \mathrm{H}\right] \mathrm{TdR}$ incorporation was $172 \pm 80$ excipient vs. $142 \pm 24$ rhIGF-1). Data are expressed as SIs after subtraction of the autologous control. Bars show mean \pm SD.

and $C$ (Figs. 2, 4, 5). The initial differences could be due to many factors including the age or breeding history of the mice because they were from retired breeding colonies and as such probably varied between shipments. However, despite these differences, equivalent effects of rhIGF-1 were seen in each experiment.

Effect of rhIGF-1 on cell-mediated responses. Experiments were performed to assess the effects of rhIGF-1 on the mixed lymphocyte response. The results in Fig. 6 show that, unlike the stimulatory effects on the $\mathrm{T}$ cell mitogenic response, rhIGF1 failed to enhance the proliferative response to allogeneic splenocytes. Thus antigen-specific $T$ cell responses was unaltered by $14 \mathrm{~d}$ of rhIGF-1 treatment.

Effect of rhIGF-1 on IgG synthesis. Given the large increases in B cell number after rhIGF-1 treatment, we examined

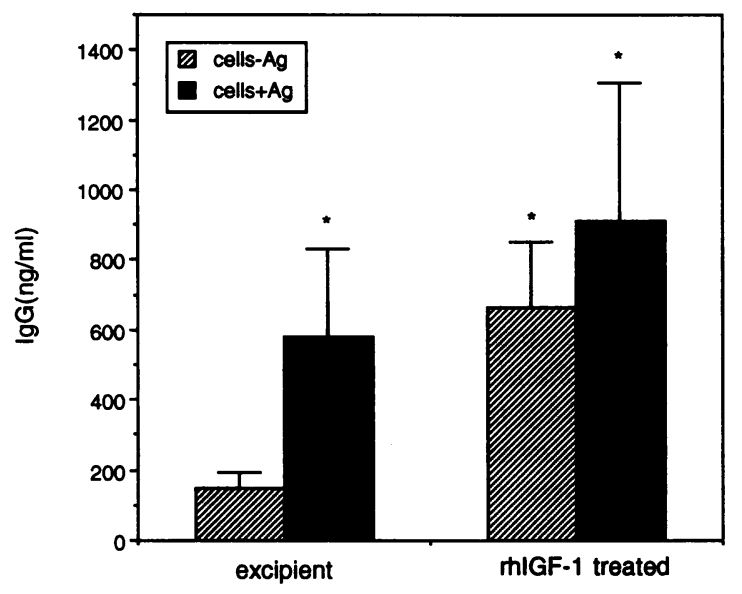

Figure 7. Increased IgG synthesis following in vivo treatment with rhIGF-1. Spleen cells from mice boosted $14 \mathrm{~d}$ previously with $1 \mu \mathrm{g}$ $\mathrm{DNP}_{2} \mathrm{OA}$ in $1 \mathrm{mg}$ of alum were cultured in triplicate in the presence or absence of DNP-HSA. After $5 \mathrm{~d}$ the supernatants from the cultures were harvested and assayed for total IgG by ELISA. All groups were compared to (excipient cells $-\mathrm{Ag}$ ). 
the possibility that $\mathrm{B}$ cell responses to antigenic stimulation might be affected by hormone treatment. As can be seen in Fig. 7, the baseline level of immunoglobulin production by splenic B cells from the treated mice was twice that of control lymphocytes. Similarily, when restimulated with exogenous antigen, additional IgG secretion occurred and again the level of synthesis was greater in the cultures of splenocytes from 14-d-treated mice compared with controls. Indeed, the level of synthesis in the antigen stimulated cultures of splenocytes from the control mice was equivalent to the baseline level of immunoglobin production of the splenocytes from the rhIGF-1-treated mice. However, in vitro antigen stimulation of splenocytes from rhIGF-1 treatment did not significantly increase IgG synthesis over the baseline level produced by these cells. Because the level of synthesis was so high in the baseline cultures of splenocytes from rhIGF-1-treated mice, this level may reflect the optimal antibody response which can be achieved using these culture conditions. An attempt was made to measure antigenspecific IgG. However, the presence of antigen in the culture supernatants interfered with the ability to measure $\mathrm{DNP}_{2} \mathrm{OA}$ specific immunoglobulin using an antigen-specific ELISA.

\section{Discussion}

IGF-1 was once referred to as a "somatomedin" to indicate that it mediated the whole-body growth-promoting activity of GH (20), but was later named IGF-1 in recognition of its insulin-like metabolic activities (21). It is therefore surprising that IGF-1, normally considered to be a metabolic hormone with anabolic and growth-promoting activity, acts as a growth factor for cells of the immune system.

Previous studies in mice had centered on the effects of IGF1 on body growth, in particular in Snell dwarf mice. Holder et al. (22) and Van Buul-Offers et al. (23) both reported that IGF-1 could have anabolic activity in these mice when given by subcutaneous injection. In the Little mouse (lit/lit), a strain that is GH-deficient (and therefore IGF-deficient), rhIGF-1 given four times a day (at a total daily dose of $3 \mathrm{mg} / \mathrm{kg}$ per d) by subcutaneous injection had anabolic effects (24). In normal mice we found that when given by subcutaneous infusion similar doses ( $4 \mathrm{mg} / \mathrm{kg}$ per $\mathrm{d}$ ) of rhIGF-1 were necessary to stimulate whole-body growth. Similar doses of rhIGF-1 have been also shown to be necessary to stimulate anabolism in rats where it has become standard practice to infuse rather than to inject rhIGF-1 to produce anabolic effects (see review in reference 25 ).

The results reported herein establish that infusions of rhIGF-1 in adult mice produce similar changes in organ growth to those seen with rhIGF-1 infusions in GH-deficient rats. For example, there were large growth responses in the kidney, spleen, and thymus, whereas liver and heart did not increase in weight. The 7- and 14-d treatment regimes produced similar increases in weight gains and organ growth. It is therefore unclear whether treatment with rhIGF-1 for longer than $14 \mathrm{~d}$ would produce a greater and sustained weight gain, as has been shown for $\mathrm{GH}$ in adult rats (26).

We also demonstrate for the first time that the administration of rhIGF-1 to normal mice can produce significant alterations in immune responsiveness. The mice responded to the rhIGF-1 with an increased spleen and thymus weight due to a significant increases in lymphocytes in these organs. An in- crease in PNA receptor binding, long known to be a marker for immature thymocytes (27), was observed in the thymocytes from the treated mice, suggesting the appearance of new thymic immigrants as a result of hormone treatment. Within $\mathrm{T}$ cell subsets in the spleen, there were preferential increases in the numbers of $\mathrm{CD}^{+}$cells. There were also significant increases in splenic $T$ and $B$ cell mitogenic responses after $2 \mathrm{wk}$ of hormone treatment. Although a decrease in mitogen responses was observed after $7 \mathrm{~d}$ of rhIGF-1 administration, this may have been due to population of the periphery by immature lymphocytes which show poor mitogen responses. However, after $14 \mathrm{~d}$ these cells may have matured and regained mitogen responsiveness. Such differences in mitogen responsiveness have been reported in ontogenic studies in which mitogen responses of peripheral lymphocytes continue to increase as an animal matures (28). In contrast, the allogeneic response was unchanged by rhIGF-1 treatment, suggesting that overall increases in $T$ cell responses do not result from rhIGF-1 treatment. However, it can not be ruled out that a longer treatment period might produce effects on this response as well.

Interestingly, B cell responses to antigen as measured by IgG production were significantly increased after treatment. More antibody was detected in cultures of splenocytes from rhIGF-1 mice whether or not antigen was added to the wells. In that these assays are performed on equal cell numbers, these data suggest that more B cells were primed as a result of the hormone or rhIGF-1 enhanced the clonal expansion of the primed cells. The former hypothesis is more likely inasmuch as the ratio of $B$ cells to $T$ cells was increased by the treatment. Furthermore, in bone marrow transplant studies, rhIGF-1 increased the rate of $\mathrm{T}$ and $\mathrm{B}$ cell repopulation of the periphery after lethal irradiation (Jardieu and Clark, unpublished observations), suggesting that rhIGF-1 acts at the level of the bone marrow rather than inducing proliferation of peripheral lymphocytes. Indeed, a recent article (29) indicates that IGF-1 is produced locally by bone marrow stromal cells and may play a role in regulating primary $B$ cell lymphopoiesis. In addition, a recent report indicates that IGF-1 may promote survival of hemopoietic precursors by inhibiting apoptosis (30). Additional experimentation is necessary to identify the site(s) of action of rhIGF-1 on B cell development.

Although a number of cytokines and growth factors such as IL-3, GM-CSF, and G-CSF are known to increase monocyte and granulocyte numbers, there are few reports of increases in lymphocyte counts in vivo $(31,32)$. Treatment of cancer patients with IL-2 does lead to increases in $\mathrm{T}$ cell number and cellular immunity (33). In vivo administration of IL-1 to mice has been shown to increase total WBC counts, largely granulocytes, and to be beneficial in the treatment of microbial infections (34). Treatment with endotoxin (35), a potent B cell mitogen used to induce endogenous cytokine production, has been unsuccessful in increasing B cell numbers in the blood. Whereas endotoxin induced IL-6 and TNF- $\alpha$, cytokines with lymphocyte growth-promoting activities, only peripheral granulocyte counts increased. rhIGF-1 also failed to increase PBLs, but striking increases in $B$ and $T$ cell numbers occurred in all peripheral lymphoid organs examined. Thus the B cell lymphopoiesis induced by rhIGF-1 is quite unusual.

It is unclear as to which of the well-characterized activities of IGF-1 are mediated in an endocrine, paracrine or autocrine manner. Because IGF-1 can be locally produced by lympho- 
cytes or stromal cells $(28)$, it is likely that locally produced IGF-1 may play an autocrine role for these cells. However, it is clear from the results presented herein, that exogenous administration of rhIGF-1 has clear effects on lymphoid tissues, which raises the possibility of an endocrine role for IGF-1 on lymphoid tissues. Likewise for $\mathrm{GH}$, a recent report indicates that daily injections of $\mathrm{GH}$ results in the reappearance of $\mathrm{CD}^{+} /$ $\mathrm{CD}^{+}$cells within the thymus of $\mathrm{DW} / \mathrm{J}$ mice which are normally deficient in these double-positive thymocytes (36). In other experiments we have found that infusions of rhGH induce higher blood IGF-1 concentrations than repeated daily injections of an equivalent amount of $\mathrm{rhGH}$. Further, infusions of either rhIGF-1 or hGH had a much greater effect on lymphoid tissues than daily injections of these hormones. Regardless of the mode of administration, rhIGF- 1 is significantly more potent in inducing alterations in immune parameters than is GH (Clark, et al., manuscript in preparation). It is possible that the effects seen with $\mathrm{GH}$ in the $\mathrm{DW} / \mathrm{J}$ mice are mediated by $\mathrm{GH}$ induction of IGF-1.

At present it is difficult to rationalize why the somatogenic hormones GH and IGF-1 should have these major effects on the cells of the immune system. In states of stress, illness, or malnutrition blood IGF-1 concentrations tend to fall in humans (37), and after an illness it has been reported that the thymus can prematurely involute (38). The involvement of the endocrine system in this process, particularly of $\mathrm{GH}$ and IGF-1 remain to be explored. Similar processes may occur in aging where both GH and IGF-1 concentrations decline, in part coincident with a decline in the immune system. The present demonstrations of the ability of rhIGF-1 to regenerate a thymus in an older animal suggests that the involution of the thymus with age might also be affected by GH and IGF-1 status. In nutritional deficiency, which can lead to IGF-1 deficiency, or in aged humans, who are immune compromised compared to younger people, IGF-1 status may be an important factor in the maintenance of immune competence. Because it is known that rhIGF-1 and rhGH are anabolic in several animal models, including those of immune deficiency, we would expect similar anabolic activity in humans in immunedeficient states. In addition to this anabolic activity, we now show evidence in laboratory animals that treatment with rhIGF-1 has positive effects on the immune system. We must await the results of on-going clinical trials with rhIGF-1 to discover whether or not rhIGF-1 will be useful as a therapeutic agent in immune-deficient states in humans.

\section{Acknowledgments}

We wish to thank Stuart Builder for supplying rhIGF-1, Abbie Celniker for the rhIGF-1 assay, and David Finkle and Deborah Mortensen for excellent technical assistance.

\section{References}

1. Froesch, E. R., H. P. Guler, M. Ernst, C. Schmid, E. Scheiwiller, and J. Zapf. 1987. Growth promoting and hypoglycemic effects of human recombinant IGF-1 in vivo in the context of in vitro actions of IGF-1. In Growth Hormone Basic and Clinical Aspects. O. Isaksson, C. Binder, K. Hall, and B. Hokfelt, editors. Elsevier, Amsterdam. 321-336.

2. Guler, H. P., J. Zapf, E. Scheiwiller, and R. Froesch. 1988. Recombinant human insulin-like growth factor-1 stimulates growth and has distinct effects on organ size in hypophysectomized rats. Proc. Natl. Acad. Sci. USA. 85:4889-4893.
3. Skottner, A., R. G. Clark, L. Fryklund, and I. Robinson. 1989. Growth responses in a mutant dwarf rat to human growth hormone and recombinant human insulin-like growth factor-1. Endocrinology. 124:2519-2526.

4. Binz, K., P. Joller, P. Froesch, H. Binz, J. Zapf, and E. R. Froesch. 1990. Repopulation of the atrophied thymus in diabetic rats by insulin-like growth factor-1. Proc. Natl. Acad. Sci. USA. 87:3690-3694.

5. Kelley, K. 1990. The role of growth hormone in modulation of the immune response. Ann. N.Y. Acad. Sci. 594:95-118.

6. Ammann, A. 1988. Growth hormone and immunity. In Human Growth Hormone-Progress and Challenges. L. Underwood, editor. Marcel Dekker, Inc. New York. 243-253.

7. Weigent, D. A., and J. E. Blalock. 1990. Growth hormone and the immune system. Prog. Neuroendocrinimmunol. 3:231-241.

8. Fabris, N., W. Pierpaoli, and E. Sorkin. 1971. Hormones and immunological capacity. III. The immunodeficiency disease of the hypopituitary Snell-Bragg dwarf mouse. Clin. Exp. Immunol. 9:209-225.

9. Murphy, W. J., S. K. Durum, and D. L. Longo. 1992. Human growth hormone promotes engraftment of murine and human $\mathrm{T}$ cell in severe combined immunodeficient mice. Proc. Natl. Acad. Sci. USA. 89:4481-4485.

10. Timsit, J., W. Savino, B. Safieh, P. Chanson, M. C. Gagnerault, J. F. Bach, and M. Dardenne. 1992. Growth hormone and insulin-like growth factor-1 stimulate hormonal function and proliferation of thymic epithelial cells. J. Clin. Endocrinol. Metab. 75:183-188.

11. Kelley, K. W. 1989. Growth hormone, lymphocytes and macrophages. Biochem. Pharmacol. 38:705-713.

12. Khansari, D. N., and T. Gustad. 1991. Effects of long-term, low-dose growth hormone therapy on immune function and life expectancy of mice. Mech Aging Dev. 57:87-100.

13. Geffner, M. E., N. Bersch, B. M. Lippe, R. G. Rosenfeld, R. L. Hintz, and D. W. Golde. 1990. Growth hormone mediates the growth of T-lymphoblast cell lines via locally generated insulin-like growth factor-1. J. Clin. Endocrinol. Metab. 71:464-469.

14. Tapson, V. F., M. Boni Schnetzler, P. F. Pilch, D. M. Center, and J. S. Berman. 1988. Structural and functional characterization of the human T-lymphocyte receptor for insulin-like growth factor-1 in vitro. J. Clin. Invest. 82:950957.

15. Stuart, C. A., R. T. Meehan, L. S. Neale, N. M. Cintron, and R. W. Furlanetto. 1991. Insulin-like growth factor-1 binds selectively to human peripheral blood monocytes and B-lymphocytes. J. Clin. Endocrinol. Metab. 72:11171122.

16. Schimpff, R. M., A. M. Repellin, A. Salvatoni, G. Thieriot-Prevost, and P. Chatelian. 1983. Effect of purified somatomedins on thymidine incorporation into lectin-activated human lymphocytes. Acta. Endocrinol. 102:21-26.

17. Merchav, S., I. Tatarsky, and Z. Hochberg. 1988. Enhancement of human granulopoiesis in vitro by biosynthetic insulin-like growth factor-1/somatomedin $\mathrm{C}$ and human growth hormone. J. Clin. Invest. 81:791-795.

18. Beschorner, W. E., J. Divic, H. Pulido, X. Yao, P. Kenworthy, and G. Bruce. 1991. Enhancement of thymic recovery after cyclosporine by recombinant human growth hormone and insulin-like growth factor-1. Transplantation. 52:879-884.

19. Ranges, G. E., M. Bombara, R. Aiyer, G. Rice, and M. Palladino. 1989. Tumor necrosis factor- $\alpha$ as a proliferative signal for IL-2 dependent T cell line: strict species specificity. J. Immunol. 142:1203-8.

20. Daughaday, W. H., K. Hall, M. S. Raben, W. D. Salmon, J. L. Van den Brande, and J. J. Van Wyk. 1972. Somatomedin: proposed designation for sulphation factor. Nature (Lond.). 235:107.

21. Daughaday, W. H., K. Hall, M. S. Raben, W. D. Salmon, J. L. Van den Brande, and J. J. Van Wyk. 1987. On the nomenclature of the somatomedins and insulin-like growth factors. J. Clin. Endocrinol. Metab. 65:1075-1076.

22. Holder, A. T., E. M. Spencer, and M. A. Preece. 1981. Effect of bovine growth hormone and a partially pure preparation of somatomedin on various growth parameters. J. Endocrinol. 89:275-282.

23. Van Buul-Offers, S., I. Ujeda, and J. L. Van den Brande. 1986. Biosynthetic somatomedin C (SMC/IGF-1) increases the length and weight of Snell dwarf mice. Pediatr. Res. 20:825-827.

24. Woodall, S. M., B. H. Breier, U. O'Sullivan, and P. D. Gluckman. 1991. The effect of frequency of subcutaneous insulin-like growth factor-1 administration on weight gain in growth hormone deficient mice. Horm. Metab. Res. 23:581-584.

25. Ballard, F. J., F. M. Tomas, L. C. Read, S. E. Knowles, P. C. Owens, A. B. Lemmey, A. A. Martin, J. R. E. Wells, J. C. Wallace, and G. L. Francis. 1991. Effects of IGF-1 and IGF analogs on growth during catabolic states in rats. In Modern concepts of insulin-like growth factors. E. M. Spencer, editor. Elsevier, Amsterdam. 617-627.

26. Groesbeck, M. D., A. F. Parlow, and W. H. Daughaday. 1987. Stimulation of supranormal growth in prepubertal, adult plateaued, and hypophysectomized female rats by large doses of rat growth hormone: physiological effects and adverse consequences. Endocrinology. 120:1963-1975. 
27. Schuurman, H., P. Brekelmans, T. Dacmen, R. Broekhuizen, and L. Kates. 1983. $T$ cell maturation in the human thymus and tonsil: peanut agglutinin binding $\mathrm{T}$ lymphocytes in thymus and tonsil differ in maturation stage. Clin. Immunol. Immunopathol. 29:271-81.

28. Dzlanski, R. 1985. Ontogenic development of proliferation and polyclonal antibody responses to staphylococal peptidoglycan, protein A and cell walls in mice. Dev. Comp. Immunol. 9:119-30.

29. Landreth, K. S., R. Narayanan, and K. Dorshkind. 1992. Insulin-like growth factor-1 regulates Pro-B-cell differentiation. Blood. 80:1-6.

30. Rodriguez-Tarduchy, G., M. Collins, I. Garcia, and A. López-Rivas. 1992 Insulin like growth factor-1 inhibits apoptosis in IL-3 dependent hemopoetic cells. J. Immunol. 149:535-40.

31. Zurzrock, R., Z. Estrov, M. Talpaz, and J. U. Guterman. 1991. Cytokines in tumor therapy. Am. J. Clin. Oncol. 14:45-50.

32. Atkinson, K., C. Matias, A. Guiffre, R. Seymour, M. Cooley, J. Biggs, V. Munro, and S. Gillis. 1991. In vivo administration of G-CSF, GM-CSF, Interleukin-1 (IL-1) and IL-4 alone and in combination after allogeneic murine hematopoietic stem cell transplantation. Blood. 77:1376-82.
33. Charak, B. S., G. D. Choushaary, M. Teff, and A. Mazzurnmder. 1992. Interleukin-2 in bone marrow transplantation preclinical studies. Bone Marrow Transplant. 10:103-11.

34. Leshem, B., R. Dekel, H. Bercovier, R. Tchakirov, I. Polacheck, Z. ZakayRomes, M. Scheesinger, and E. Kedar. 1992. Cytokine induced resistance to microbial infections in normal, immunosuppressed and bone marrow transplanted mice. Bone Marrow Transplant. 9:471-7.

35. Mackensen, A., C. Galanos, and R. Engelhardt. 1991. Treatment of cancer patients with endotoxin induces release of endogenous cytokines. Pathobiology. 59:264-7.

36. Murphy, W., S. Durum, and D. Longo. 1992. Role of neuroendocrine hormones in murine T-cell development. J. Immunol. 149:3851-57.

37. Underwood, L. E., J. P. Thissen, B. M. Moats-Staats, E. Bruton, M. Maes and J. M. Ketelslegers. 1991. Nutritional regulation of IGF-1 and postnatal growth. In Modern Concepts of Insulin-like Growth Factors. E. M. Spencer, editor. Elsevier, Amsterdam. 37-47.

38. Ham, A. W. 1965. The Thymus. In Histology 5th edition. J. P. Lippincott Co., Philadelphia. 338-348. 